\title{
VOLTAMMETRIC DETERMINATION OF Pd(II) USING 5-HYDROXYIMINO-4-IMINO-1,3-THIAZOLIDIN-2-ONE AFTER A THERMAL ACTIVATION OF THE INTERACTION
}

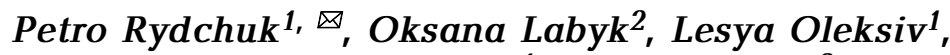 \\ Oleksandr Tymoshuk ${ }^{1}$, Taras Chaban ${ }^{3}$
}

https://doi.org/10.23939/chcht15.03.324

\begin{abstract}
The interaction of $\mathrm{Pd}(\mathrm{II})$ with 5-hydroxyimino4-imino-1,3-thiazolidin-2-one (HITO) was investigated over the $\mathrm{pH}$ range of 1.0-10.0. Optimal conditions for the voltammetric determination of $\mathrm{Pd}(\mathrm{II})$ were established. A new voltammetric method of Pd(II) determination by the peak of complex using $\mathrm{NaCl}$ as a supporting electrolyte at $\mathrm{pH} 2.0$ was developed with the limit of detection $2.0 \cdot 10^{-7} \mathrm{M}$. The study of the method's selectivity was presented in the work. The correctness of the method was confirmed by the analysis of model solutions and the real sample (resistor SP5-35B).
\end{abstract}

Keywords: palladium, voltammetric determination, azolidone, oxime, thermal activation.

\section{Introduction}

Derivatives of azolidone are the class of organic substances with the proven antimicrobial [1-2] and anticancer [3] activity, so they are promising drugs. The study of some azolidone and thiazole as analytical reagents showed the perspective of their using for the spectrophotometric determination of numerous metal ions: Pd(II) [4-9], Ru(IV) [10], Rh(III) [11], Pt(IV) [12], Ir(IV) [9, 13], Cu(II) [14-16], Ni(II) [17], Co(II) [18], Zn(II), $\mathrm{Cd}(\mathrm{II})$ [16] Ta $\mathrm{Hg}$ (II) [19]. The detected catalytic effects of the analytical forms of platinum group metals with 5-hydroxyimino-4-imino-1,3-thiazolidin-2-one made it possible to determine selectively $\mathrm{Ru}(\mathrm{IV})$ [20], $\mathrm{Rh}(\mathrm{III})$ [21] and $\mathrm{Pt}(\mathrm{IV})$ [22] at nanogram levels. This fact indicates the perspective of using HITO as an organic analytical reagent in the voltammetric analysis. Usual analytical

\footnotetext{
${ }^{1}$ Department of Analytical Chemistry, Ivan Franko National University of Lviv, 6, Kyryla i Mephodia St., 79005 Lviv, Ukraine

${ }^{2}$ Central Research Laboratory and Laboratory of Industrial Toxicology, Danylo Halytsky Lviv National Medical University, 69, Pekarska St., 79010 Lviv, Ukraine

${ }^{3}$ Department of General, Bioinorganic, Physical and Colloidal Chemistry, Danylo Halytsky Lviv National Medical University, 52, Pekarska St., 79010 Lviv, Ukraine

peter_rydchuk@yahoo.com

(c) Rydchuk P., Labyk O., Oleksiv L., Tymoshuk O., Chaban T., 2021
}

reagents for the voltammetric determination of $\mathrm{Pd}(\mathrm{II})$ are oxime and amine derivatives [23-30]. Complex of palladium(II) with dimethylglyoxime $\left(\mathrm{H}_{2} \mathrm{Dm}\right)$ is widely used as an analytical form for the spectrophotometric and voltammetric determination of Pd(II) [26-29]. Different working electrodes modified with bismuth were proposed as an alternative to a dropping mercury electrode [26-29]. Therefore, authors [26] proposed a voltammetric sensor based on the renewable bismuth bulk annular band working electrode for palladium(II) detection via the differential pulse adsorptive stripping voltammetry. It is also possible to use an antimony film coated on a screen-printed carbon electrode or bismuth screen-printed electrode by a differential pulse voltammetry [27-28]. The use of dimethylglyoxime allows simultaneous determination of several platinum metals by differential pulse adsorptive stripping voltammetric techniques using screen-printed carbon electrode coated with a bismuth film [29-30]. It is worth noting that the high sensitivity of the determination in the described methods is ensured only by the types of voltammetry used in the work, and not by the electrode material. The decisive role of a variety of voltammetric methods is easily seen in [31], where the possibility of the adsorption stripping voltammetric determination of $\mathrm{Pd}(\mathrm{II})$ in the form of $\mathrm{Pd}(\mathrm{HDm})_{2}$ on a dropping mercury electrode is shown. In addition to the adsorptive concentration in modern voltammetric methods, $\mathrm{Pd}(\mathrm{HDm})_{2}$ was proposed to be determined by a stripping voltammetry with the previous extraction concentration [32]. However, the combination of a complex concentration procedure does not give significant advantages over the described methods with modified electrodes.

\section{Experimental}

Voltammetric measurements were carried out on a digital device equipped with a personal computer MTech OVA-410 [33] and a three-electrode cell. An indicator dropping mercury electrode, a saturated calomel reference electrode and platinum wire auxiliary electrode were used. 
The parameters for voltammetric measurements were as following: waveform component voltage - triangular; scan rate $-1.0 \mathrm{~V} / \mathrm{s}$; voltammograms were recorded at room temperature $(\sim 293 \mathrm{~K})$. The dissolved oxygen from an electrolytic cell was removed by a purified argon for $10 \mathrm{~min}$.

The $\mathrm{pH}$ value of solutions was controlled potentiometrically using the $\mathrm{pH}$-meter $\mathrm{pH}-150 \mathrm{M}$ with a combination glass electrode. The $\mathrm{pH}$ values $( \pm 0.05)$ were adjusted by $\mathrm{HCl}$ and $\mathrm{NaOH}$ (pH 1.0-3.0; supporting electrolyte $\mathrm{NaCl}$ ); $\mathrm{CH}_{3} \mathrm{COOH}$ and $\mathrm{NaOH}(\mathrm{pH} 3.5-7.0$; supporting electrolyte $\mathrm{CH}_{3} \mathrm{COONa}$ ), $\mathrm{NH}_{3} \cdot \mathrm{H}_{2} \mathrm{O}$ and $\mathrm{HCl}$ (pH 7.0-10.0; supporting electrolyte $\mathrm{NH}_{4} \mathrm{Cl}$ ).

Voltammetric investigations were carried out using solutions of $\operatorname{Pd}(\mathrm{II})$ chloride, which were prepared from the exact amount of metallic palladium $(\omega=99.99 \%)$ according to [34].

The selectivity of the voltammetric determination of $\mathrm{Pd}(\mathrm{II})$ in the presence of the accompanying ions $\mathrm{Rh}(\mathrm{III}), \mathrm{Ir}(\mathrm{IV}), \mathrm{Ru}(\mathrm{IV})$ was studied. Standard solutions of $\mathrm{Rh}(\mathrm{III}), \operatorname{Ir}(\mathrm{IV}), \mathrm{Ru}(\mathrm{IV})$ were prepared by sintering the exact amounts of metal $(\omega=99.99 \%)$ with 5 -fold excess of $\mathrm{BaO}_{2}$ and subsequent dissolution of the obtained fusion in $3 \mathrm{M} \mathrm{HCl}$ [24]. A stock solution of Os(IV) was prepared by dissolving the appropriate quantity of $\mathrm{OsO}_{4}$ in conc. $\mathrm{HCl}$ according to [35]. A stock solution of $\mathrm{Pt}(\mathrm{IV})$ was prepared according to [36]. The solutions were standardized according to [37-38]. The predominant existence form of Ir(IV) was found spectrophotometrically by comparing the electronic absorption spectra of the obtained solution with the literature data [23-24, 39]. Solutions of extraneous metal ions (Ca(II), $\mathrm{Ba}(\mathrm{II}), \mathrm{Al}(\mathrm{III}), \mathrm{Cu}(\mathrm{II}), \mathrm{Zn}(\mathrm{II}), \mathrm{Cd}(\mathrm{II})$, $\mathrm{Pb}(\mathrm{II}), \mathrm{Mn}(\mathrm{II}), \mathrm{Fe}(\mathrm{III}), \mathrm{Co}(\mathrm{II}), \mathrm{Ni}(\mathrm{II}))$ were prepared by dissolving the exact amount of the salt of the corresponding metal (analytical grade) in $1 \mathrm{M}$ hydrochloric acid. The supporting electrolytes $\left(\mathrm{NaCl}, \mathrm{CH}_{3} \mathrm{COONa}, \mathrm{NH}_{4} \mathrm{Cl}\right)$ were prepared by dissolving the exact amount of the corresponding salt (analytical grade) in distilled water. Stock solutions $\left(5 \cdot 10^{-3} \mathrm{M}\right)$ of HITO were prepared by dissolving the exact amount of reagent in ethanol (96\%).

Voltammetric method of palladium determination based on the cathode peak of complex of Pd(II) with 5-hydroxyimino-4-imino-1,3-thiazolidin-2-one. The aliquot of $\mathrm{Pd}(\mathrm{II})$ solution within the limits of $2.5-53 \mu \mathrm{g}, 0.5 \mathrm{ml}$ of $5.0 \cdot 10^{-3} \mathrm{M}$ HITO solution, $2.0 \mathrm{ml}$ of $4 \mathrm{M}$ solution of sodium chloride and $15 \mathrm{ml}$ of distilled water were placed into a $40.0 \mathrm{ml}$ chemical vessel. The needed $\mathrm{pH} 2.0$ was adjusted by adding $1 \mathrm{M} \mathrm{HCl}$ and $\mathrm{NaOH}$ (without reaching an alkaline medium). The obtained solution was heated on a water bath $(363 \mathrm{~K})$ during $30 \pm 2 \mathrm{~min}$. Then the solution was cooled to room temperature, transferred to a $25.0 \mathrm{ml}$ volumetric flask and diluted to the mark with distilled water. The working solutions were introduced into the cell and deoxygenated with argon for $10 \mathrm{~min}$. The voltammograms were recorded in the range of potentials from -0.1 to $-1.0 \mathrm{~V}$ at a scan rate of $1.0 \mathrm{~V} / \mathrm{s}$. Cathodic current was measured at the potential $-0.283 \mathrm{~V}$. The value of the analytical signal was measured relatively to the solution of the organic reagent itself. The reference solution of organic reagent was prepared similarly as those of Pd(II)-HITO complex but without adding Pd(II). The concentration of palladium(II) was determined from the calibration curve or by the method of comparison.

Preparation of the resistor SP5-35B for sample analysis. The parts of resistor containing precious metals were placed in a $150 \mathrm{ml}$ heat-resistant chemical vessel. Then we added $20 \mathrm{ml}$ of a mixture of conc. hydrochloric and nitric acids (3:1). The pieces of resistor were dissolved in a mixture of acids during heating on a sand bath (the chemical vessel was covered with a watch glass). The obtained solution was evaporated to wet salts. Then $3 \mathrm{ml}$ of conc. hydrochloric acid was added and the solution continued to be heated until the termination of the release of nitrogen oxides. This procedure can be repeated if necessary. Thus, palladium(II) was transformed into the chloride form $\left[\mathrm{PdCl}_{4}\right]^{2-}$. Then the content of the vessel was dissolved with $13 \mathrm{ml}$ of conc. $\mathrm{HCl}$, completely transferred into a $50.0 \mathrm{ml}$ measuring flask and distilled water was added to the mark.

Atomic absorption spectroscopy method for palladium determination

The aliquots of $4.8 \cdot 10^{-4} \mathrm{M}$ Pd(II) standard solutions with the volume of $1.0 ; 2.0 ; 3.0 ; 4.0 ; 5.0 \mathrm{ml}$ were introduced into $25.0 \mathrm{ml}$ flasks. Distilled water was added to the mark and the obtained solution was stirred thoroughly. Palladium(II) content was determined from the calibration curve. Atomic absorption measurements were performed using the atomic absorption spectrophotometer AAS-1N. The solution was sprayed into air - propane - butane flame and the absorbance of the solution was measured at $247.6 \mathrm{~nm}$. A hollow cathode lamp "Narva" (Hohlkatodenlampe, Deutschland) was used as a monochromatic atomic emission source [40-42].

\section{Results and Discussion}

The possibility of $\mathrm{Pd}(\mathrm{II})$ voltammetric determination using 5-hydroxyimino-4-imino-1,3-thiazolidin-2-one (Fig. 1) was investigated. The organic reagent was synthesized and purified at the Department of Organic Chemistry, Ivan Franko National University in Lviv.

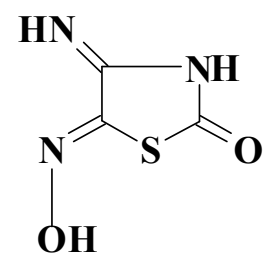

Fig. 1. Structural formula

of 5-hydroxyimino-4-imino-1,3-thiazolidin-2-one (HITO) 
The investigation of $\mathrm{pH}$ influence on the voltammetric characteristics of peaks of $\mathrm{Pd}(\mathrm{II})-\mathrm{HITO}$ system showed that the complex is formed over a wide $\mathrm{pH}$ range, viz. from 1.0 to 10.0. The appearance of the reduction peak of the complex compound $\left(E_{c}^{p}=-0.283 \mathrm{~V}\right.$, Fig. 2), and the shift of the reduction peak of the organic reagent oxime group indicates the complex formation. The reduction peak of the complex compound oxime group is shifted only on $50 \mathrm{mV}$ towards more negative potentials $\left(E_{c}^{p}=-0.530 \mathrm{~V}\right.$, Fig. 2). This indicates that Pd(II) complex with HITO does not possess high stability. Such a difference in peak potentials is not enough for the peaks of oxime group of HITO itself and Pd(II) complex with HITO to be traced on the voltammogram separately and clearly. In the presence of HITO significant excess, the cathodic peak corresponding to the reduction of the oxime group of the organic reagent could completely overlap the peak of the oxime group of the complex compound. Therefore, it is better to use the reduction peak of the complex as an analytical signal for the development of voltammetric methods of $\mathrm{Pd}(\mathrm{II})$ determination. However, the presence of two electroactive groups (oxime and imino) in HITO molecule complicates the possibility of voltammetric determination of Pd(II) by the reduction peak of the complex. It is obvious that except the reduction peaks of free HITO, also the reduction peaks of $\mathrm{Pd}(\mathrm{II})$-HITO complex related to the reduction of oxime and imino group can be registered on the voltammograms. Thus, the reduction peaks of the organic reagent and complex can be overlapped [43]. Heating of the solutions could make the measurement of the peak current of Pd(II)-HITO complex easier due to the destruction of the excess of the organic reagent. Thus, only peaks of the complex will be observed on the voltammograms in this case, and there will be no peaks of the organic reagent. It was also confirmed that heating of the solution has activated the interaction between $\operatorname{Pd}(\mathrm{II})$ and HITO. The

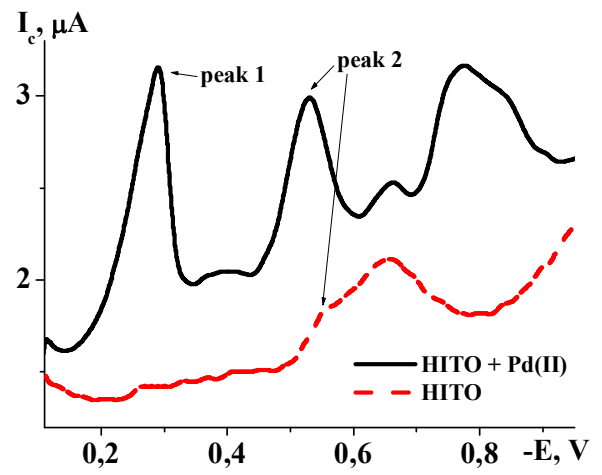

Fig. 2. Voltammograms of HITO solutions in the presence of $\mathrm{Pd}(\mathrm{II})$ and without $\mathrm{Pd}(\mathrm{II})$ after heating using $\mathrm{NaCl}$ as a supporting electrolyte $\left(C_{\mathrm{Pd}(\mathrm{II})}=2.0 \cdot 10^{-5} \mathrm{M}, C_{\mathrm{HITO}}=2.0 \cdot 10^{-5} \mathrm{M}\right.$, $\mathrm{pH} 2.0, \mu=0.3 \mathrm{M}, V=1.0 \mathrm{~V} / \mathrm{s}, \tau_{\text {heat. }}=30 \mathrm{~min}$ ) useful effects in the analysis, observed at higher temperatures, differed to those observed without heating. These effects of the complexation can be used for analytical purposes. Heating of the solution leads to the accelerating of the process of palladium(II) complexation with HITO in acidic medium, as evidenced by the significant increase of the complex peak current $\left(E_{c}^{p}=-0.283 \mathrm{~V}\right.$, Fig. 2). Instead, in the absence of palladium(II), the hydrolysis of HITO oxime group has occurred during heating of the solutions, and the current of its cathode peak decreases $\left(E_{c}^{p}=-0.530\right.$ V, Fig. 2).

The investigation of the heating effect on the voltammetric characteristics of Pd(II)-HITO system using the acetate buffer solution has showed that the peak of the complex was not observed at this background electrolyte. The absence of the reduction peak of the complex may be due to the conversion of $\mathrm{Pd}$ (II) to a non-electroactive form during the hydrolysis. However, the other effect was observed. The reduction peak of oxime group of HITO decreased in the presence of $\mathrm{Pd}(\mathrm{II})\left(E_{c}^{p}=-0.451 \mathrm{~V}\right.$, Fig. 3). The use of this effect for analytical purposes could be accompanied by some inconveniences. The analytical signal should be measured as a difference between the peak height of the oxime group in the HITO solution and the height of the same peak in the HITO solution in the presence of $\mathrm{Pd}(\mathrm{II})$. Thus, it will be necessary to prepare an additional solution of HITO, as a reference.

The heating of HITO solutions in the presence of $\operatorname{Pd}(\mathrm{II})$ in the medium of ammonia buffer solution also encouraged the complexation. The decrease of the current peak corresponding to the oxime group of HITO $\left(E_{c}^{p}=-0.451 \mathrm{~V}\right.$, Fig. 4), and the shift of the complex peak towards more negative values $\left(E_{c}^{p}=-0.925 \mathrm{~V}\right.$, Fig. 4) indicated the complexation. However, the detected effects do not prevail over the known voltammetric method of palladium(II) determination in the form of ammonia complexes $\left(E_{c}^{p}=-0.829 \mathrm{~V}\right.$, Fig. 4$)$.

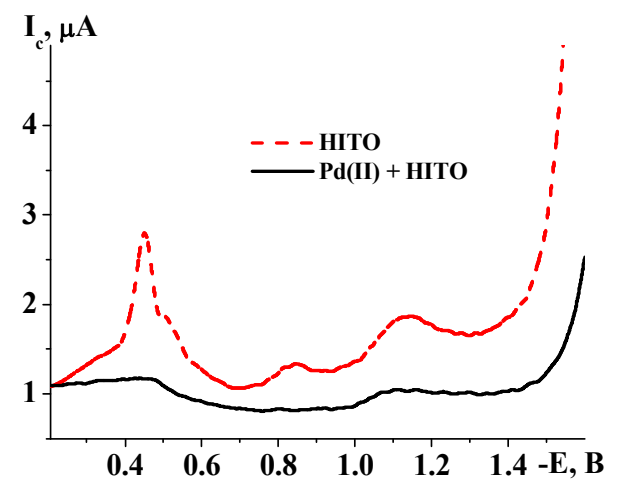

Fig. 3. Voltammograms of HITO solution in the presence of $\mathrm{Pd}(\mathrm{II})$ and without $\mathrm{Pd}(\mathrm{II})$ after heating using acetate buffer as a supporting electrolyte $\left(C_{\mathrm{Pd}(\mathrm{II})}=2.0 \cdot 10^{-5} \mathrm{M}, C_{\mathrm{HITO}}=2.0 \cdot 10^{-5} \mathrm{M}\right.$, $\mathrm{pH} 6.0, \mu=0.3 \mathrm{M}, V=1.0 \mathrm{~V} / \mathrm{s}, \tau_{\text {heat. }}=30 \mathrm{~min}$ ) 


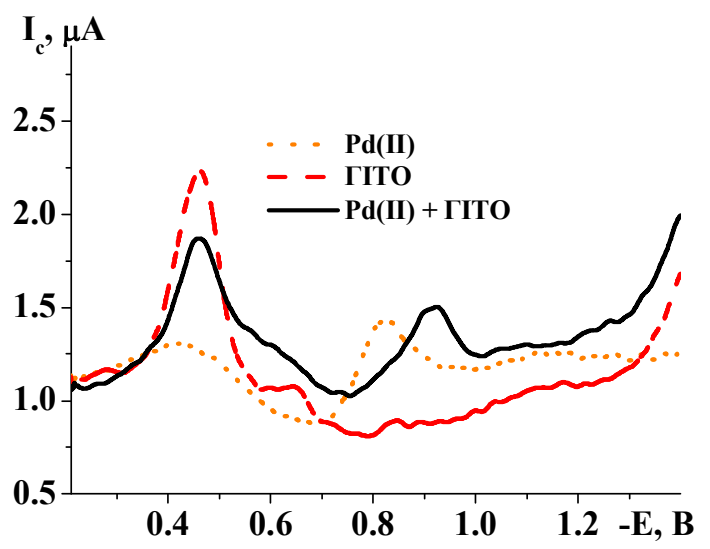

Fig. 4. Voltammograms of Pd(II), HITO and Pd(II) in the presence of HITO after heating using ammonia buffer as a supporting electrolyte $\left(C_{\mathrm{Pd}(\mathrm{II})}=2.0 \cdot 10^{-5} \mathrm{M}, C_{\mathrm{HITO}}=2.0 \cdot 10^{-5} \mathrm{M}\right.$, $\mathrm{pH} 9.0, \mu=0.3 \mathrm{M}, V=1.0 \mathrm{~V} / \mathrm{s}, \tau_{\text {heat. }}=30 \mathrm{~min}$ )

Fig. 6. The calibration curve of the voltammetric determination of Pd(II) by the cathode peak of the complex with HITO after heating $\left(C_{\text {НІтO }}=1.0 \cdot 10^{-4} \mathrm{M}, E_{c}^{p}=-0.283 \mathrm{~V}, \mu=0.3 \mathrm{M}\right.$,

$$
V=1.0 \mathrm{~V} / \mathrm{s}, \tau_{\text {heat. }}=30 \mathrm{~min} \text { ) }
$$

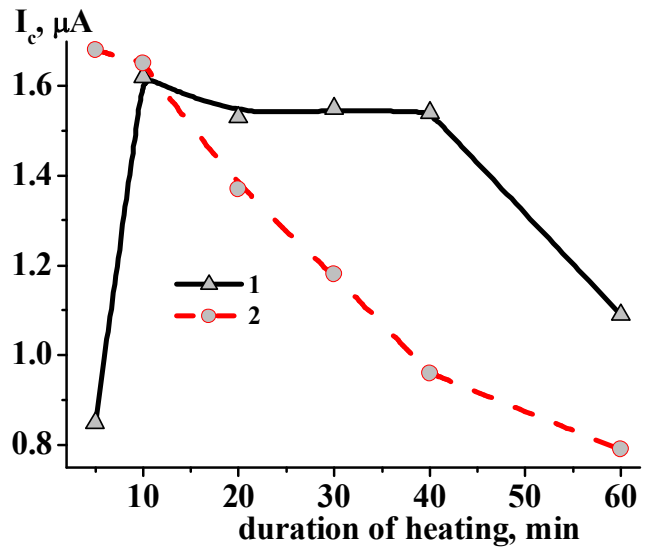

Fig. 5. The effect of heating duration on the height of cathodic peaks of Pd(II) complex with HITO: the peak of the complex

(1) and the peak of oxime group (2); $\left(C_{\mathrm{Pd}(\mathrm{II})}=2.0 \cdot 10^{-5} \mathrm{M}\right.$, $\left.C_{\text {HITO }}=2.0 \cdot 10^{-5} \mathrm{M}, \mu=0.3 \mathrm{M}, V=1.0 \mathrm{~V} / \mathrm{s}\right)$

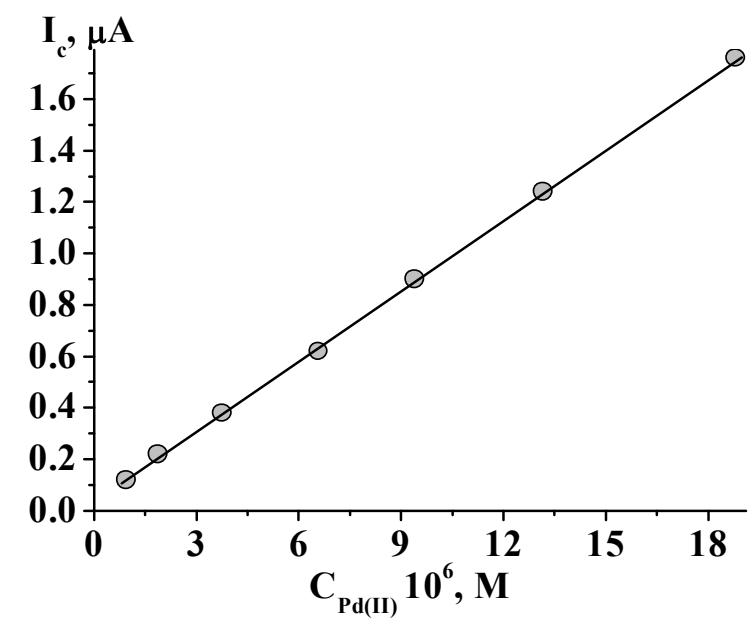

range of more than one order. Extending the range of Pd(II) content that can be determined toward higher concentrations, is not necessary, because high concentrations of $\operatorname{Pd}(\mathrm{II})$ can be determined by chemical methods.

The proposed method has good metrological characteristics (Table 1), it is simple in the performance, as well as it is characterized by an accessible hardware and it is quite suitable for the analytical control of palladium(II) content in industrial wastes.

In addition, the reduction peak of the complex compound is observed at the potential where there is practically no overlay of reduction peaks of most of interfering metal ions, except $\mathrm{Cu}$ (II). The developed method is characterized by the good selectivity towards ions of accompanying metals, in particular, platinum (Table 2). The choice of elements for the selectivity study was based on the qualitative compositions of the investigated samples. current on the concentration of $\mathrm{Pd}(\mathrm{II})$ ions is shown in Fig 6. This dependence is straight linear in the concentration 
Table 1

Metrological characteristics of the voltammetric determination of Pd(II) using the cathode peak of Pd(II) complex with HITO after heating $\left(C_{\text {HITO }}=1.0 \cdot 10^{-4} \mathrm{M} ; E_{c}^{p}=-0.283 \mathrm{~V}, \mathrm{pH}=\mathbf{2 . 0}\right.$; $\left.\mu=0.3 \mathrm{M}, V=1.0 \mathrm{~V} / \mathrm{s}, \tau_{\text {heat. }}=30 \mathrm{~min}\right)$

\begin{tabular}{|c|c|}
\hline Calibration equation & $\mathrm{I}=0.036+0.092 \cdot 10^{6} \mathrm{C}_{\mathrm{Pd}(\mathrm{II})}$ \\
\hline Limit of detection, $\mathrm{M}$ & $2.0 \cdot 10^{-7}$ \\
\hline Linearity range, $\mathrm{M}$ & $(0.1-2.0) \cdot 10^{-5}$ \\
\hline Correlation coefficient $R$ & 0.9999 \\
\hline
\end{tabular}

Table 2

Tolerance limits of interfering ions of Pd(II) voltammetric determination using the peak of Pd(II)-HITO complex after heating $\left(C_{\mathrm{Pd}(\mathrm{II})}=5.0 \cdot 10^{-6} \mathrm{M}, C_{\mathrm{HITO}}=1.0 \cdot 10^{-4} \mathrm{M} ; E_{c}^{p}=-\mathbf{0 . 2 8 3} \mathrm{V}\right.$, $\left.\mathbf{p H}=2.0 ; \mu=0.3 \mathrm{M}, V=1.0 \mathrm{~V} / \mathrm{s}, \tau_{\text {heat. }}=30 \mathrm{~min}\right)$

\begin{tabular}{|c|c|c|c|}
\hline Metal ion & $C_{\mathrm{Me}} / C_{\mathrm{Pd}}$ & Metal ion & $C_{\mathrm{Me}} / C_{\mathrm{Pd}}$ \\
\hline $\mathrm{Ca}(\mathrm{II})$ & $100^{*}$ & $\mathrm{Ru}(\mathrm{IV})$ & 5 \\
\hline $\mathrm{Ba}(\mathrm{II})$ & $100^{*}$ & $\mathrm{Rh}(\mathrm{III})$ & 5 \\
\hline $\mathrm{Al}(\mathrm{III})$ & 50 & $\mathrm{Ir}(\mathrm{IV})$ & $10^{*}$ \\
\hline $\mathrm{Ga}(\mathrm{III})$ & 50 & $\mathrm{Pt}(\mathrm{IV})$ & $10^{*}$ \\
\hline $\mathrm{Cu}(\mathrm{II})$ & 50 & $\mathrm{Os}(\mathrm{IV})$ & $10^{*}$ \\
\hline $\mathrm{Zn}(\mathrm{II})$ & $100^{*}$ & $\mathrm{Fe}(\mathrm{III})$ & 30 \\
\hline $\mathrm{Cd}(\mathrm{II})$ & $100^{*}$ & $\mathrm{Co}(\mathrm{II})$ & 20 \\
\hline $\mathrm{Pb}(\mathrm{II})$ & 50 & $\mathrm{Ni}(\mathrm{II})$ & 100 \\
\hline $\mathrm{Mn}(\mathrm{II})$ & 100 & $\mathrm{Sn}(\mathrm{IV})$ & 50 \\
\hline
\end{tabular}

Note: * "> higher concentrations were not investigated

The tolerance limit was considered as a value causing a $\pm 5 \%$ change in the current.

An additional advantage of the proposed background electrolyte is the possibility of the simultaneous voltammetric determination of $\mathrm{Pd}(\mathrm{II})$ and $\mathrm{Pt}(\mathrm{IV})$ in the samples, since $\mathrm{pH} 2.0$ and $0.3 \mathrm{M} \mathrm{NaCl}$ supporting electrolyte is the optimal background for the determination of $\mathrm{Pt}(\mathrm{IV})$ by the peak of the catalytic reduction of hydrogen using HITO [24].

Table 3

Accuracy of the voltammetric determination of Pd(II) with HITO in model solutions

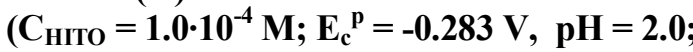
$\mu=0.3 \mathrm{M}, \mathrm{V}=1.0 \mathrm{~V} / \mathrm{s}, \mathrm{n}=3, \mathrm{P}=0.95$ )

\begin{tabular}{|c|c|c|c|}
\hline $\begin{array}{c}\text { Content of } \\
\text { matrix solution }\end{array}$ & $\begin{array}{c}\text { Added } \\
\mathrm{Pd}(\mathrm{II}), \\
\mu \mathrm{g}\end{array}$ & $\begin{array}{c}\text { Found } \mathrm{Pd}(\mathrm{II}) \\
\overline{\mathrm{x}} \pm \mathrm{S} \cdot \mathrm{t}_{\alpha} / \sqrt{\mathrm{n}, \mu \mathrm{g}}\end{array}$ & $\begin{array}{c}R S D, \\
\%\end{array}$ \\
\hline $\begin{array}{l}3.4 \mathrm{mg} \mathrm{Ba}(\mathrm{II}) \\
1.5 \mathrm{mg} \mathrm{Ni}(\mathrm{II})\end{array}$ & 26.6 & $27.5 \pm 2.5$ & 3.7 \\
$0.5 \mathrm{mg} \mathrm{Ir}(\mathrm{IV})$ & & $40.7 \pm 1.4$ & 1.4 \\
\hline $\begin{array}{c}2.4 \mathrm{mg} \mathrm{Zn(II)} \\
2.1 \mathrm{mg} \mathrm{Cd(II)}\end{array}$ & 40.0 & & \\
$3.9 \mathrm{mg} \mathrm{Pb}(\mathrm{II})$ & & & \\
\hline
\end{tabular}

The accuracy of the voltammetric determination of palladium(II) with HITO has been tested using the "added-found" method and model solutions (Table 3).

As can be seen from the results of the testing method, the error of $\mathrm{Pd}$ (II) determination does not exceed the permissible error of the method. The obtained results confirmed the correctness of the developed method and the possibility of its use in the analysis of real samples.

Voltammetric determination of $P d(I I)$ in the resistor $S P 5-35 B$

The resistor SP 5-35 B was dissolved in the mixture of acids. Since the resistor contains milligrams of silver, the obtained solution had a slight white turbidity. In order to avoid losses of $\mathrm{Pd}(\mathrm{II})$ during a filtration, formed $\mathrm{AgCl}$ was not separated and it was transferred quantitatively to the flask. The correctness of the developed voltammetric method was checked using an atomic absorption spectroscopy as a reference method in the air - propane butane flame with a hollow cathode lamp as a monochromatic atomic emission. The results of the determination of palladium content in the resistor are shown in Table 4.

Table 4

\section{Results of palladium determination in the resistor $\mathrm{SP5}-35 \mathrm{~B}$}

$\left(C_{\text {HІто }}=\mathbf{1 . 0} \cdot 10^{-4} \mathrm{M} ; E_{c}^{p}=\mathbf{- 0 . 2 8 3} \mathrm{V}, \mathrm{pH}=\mathbf{2 . 0}\right.$ $\mu=0.3 \mathrm{M}, V=1.0 \mathrm{~V} / \mathrm{s}, \mathrm{n}=3, P=0.95)$

\begin{tabular}{|l|c|c|}
\hline \multicolumn{1}{|c|}{ Method } & $\begin{array}{c}\overline{\mathrm{m}} \pm \frac{\mathrm{S} \cdot \mathrm{t}_{a}}{\sqrt{\mathrm{n}}} \\
\mathrm{mg}\end{array}$ & $\begin{array}{c}R S D, \\
\%\end{array}$ \\
\hline $\begin{array}{l}\text { Voltammetry( using the peak of } \\
\text { Pd(II)-HITO complex) }\end{array}$ & $32.6 \pm 1.0$ & 1.3 \\
\hline AAS [40-42] & $32.2 \pm 3.6$ & 4.5 \\
\hline
\end{tabular}

\section{Conclusions}

The effect of $\mathrm{pH}$ on voltammetric characteristics of cathode peaks of $\mathrm{Pd}(\mathrm{II})$-5-hydroxyimino-4-imino-1,3thiazolidin-2-one system was investigated. The complexation of $\mathrm{Pd}(\mathrm{II})$ with 5-hydroxyimino-4-imino-1,3thiazolidin-2-one in the $\mathrm{pH}$ range of $1.0-10.0$ was confirmed, as testified by the decrease of the peak of oxime group on the acetate buffer solution, by the appearance of reduction peak of complex compound and the oxime group peak shift towards more negative values on the sodium chloride supporting electrolyte in the $\mathrm{pH}$ range of 1.0-3.0. The sensitive voltammetric method of $\mathrm{Pd}(\mathrm{II})$ ions determination using the reduction peak of Pd(II) complex with 5-hydroxyimino-4-imino-1,3thiazolidin-2-one after heating during $30 \mathrm{~min}$ was developed. The developed method is relatively sensitive 
with $\mathrm{LOD}=2 \cdot 10^{-7} \mathrm{M}$. The voltammetric determination of $\mathrm{Pd}(\mathrm{II})$ using sodium chloride as a supporting electrolyte is possible in the presence of significant excesses of interfering metal ions, in particular, of platinum group metals. The proposed method has good metrological characteristics. Despite, the developed method is less sensitive in the comparison to adsorptive and extraction voltammetric methods, it does not require the use of toxic organic reagents and the complex procedure for the manufacture and the modification of electrodes; it is more expressive, reproducible, simple in the performance and demands low costing instruments.

\section{References}

[1] Tsyalkovsky V., Kutsyk R., Matiychuk V. et al.: Pharm. Chem. J., 2005, 39, 245. https://doi.org/10.1007/s11094-005-0126-8

[2] Zimenkovskii B., Kutsyk R., Lesyk R. et al.: Pharm. Chem. J., 2006, 40, 303. https://doi.org/10.1007/s11094-006-0115-6

[3] Lebedev R.: Russ. Phys. J., 2002, 45, 822.

https://doi.org/10.1023/A:1021928817028

[4] Lozynska L., Tymoshuk O.: Chem. Chem. Technol., 2013, 7, 391. https://doi.org/10.23939/chcht07.04.391.

[5] Lozynska L., Tymoshuk O., Chaban T.: Metods Objects Chem. Anal., 2014, 9, 50. https://doi.org/10.17721/moca.2014.50-54

[6] Lozynska L., Tymoshuk O., Rydchuk P.: Chem. Met. Alloys, 2014, 7, 119. https://doi.org/10.30970/cma7.0279

[7] Lozynska L., Tymoshuk O., Chaban T: Acta Chim. Slov., 2015, 62, 159. https://doi.org/10.17344/acsi.2014.866

[8] Tupys A., Tymoshuk O.: Acta Chim. Slov., 2015, 8, 59.

https://doi.org/10.1515/acs-2015-0011

[9] Lozynska L., Tymoshuk O., Vrublevs'ka T.: Mater. Sci., 2015, 50, 870. https://doi.org/10.1007/s11003-015-9795-y

[10] Tymoshuk O., Oleksiv L., Khvalbota L. et al.: Acta Chim. Slov., 2019, 66, 62. https://doi.org/10.17344/acsi.2018.4448

[11] Lozynska L., Tymoshuk O.: Voprosy Khimii i Khimicheskoi Tekhnologii, 2014, 1, 80.

[12] Lozynska L., Tymoshuk O.: Pat. UA 91160, Publ. July 25, 2014.

[13] Lozynska L., Tymoshuk O.: Visnyk Lviv Univ., 2014, 55, 275.

[14] Bazel Y., Tupys A., Ostapiuk Y. et al.: RSC Adv., 2018, 8, 15940. https://doi.org/10.1039/C8RA02039F

[15] Tupys A., Tymoshuk O., Rydchuk P.: Chem. Chem. Technol., 2016, 10, 19. https://doi.org/10.23939/chcht10.01.019.

[16] Tupys A., Tymoshuk O., Rydchuk P.: Metods Objects Chem. Anal., 2015, 10, 80. https://doi.org/10.17721/moca.2015.80-88

[17] Bazel Y., Tupys A., Ostapiuk Y. et al.: J. Mol. Liq., 2017, 242, 471. https://doi.org/10.1016/j.molliq.2017.07.047

[18] Tupys A., Tymoshuk O.: Visnyk Lviv Univ., 2013, 54, 193.

[19] Tupys A., Kalembkiewicz J., Bazel Y. et al.: J. Mol. Struct., 2017, 1127, 722. https://doi.org/10.1016/j.molstruc.2016.07.119 [20] Rydchuk P., Tymoshuk O., Patsay I.: Pat. UA 129442, Publ. Oct. $25,2018$.

[21] Rydchuk P., Shevchuk D., Tymoshuk O., Patsay I.: Pat. UA 129443, Publ. Oct. 25, 2018.

[22] Rydchuk P., Tymoshuk O., Oleksiv L. et al:: Methods Objects Chem. Anal., 2019, 14, 130. https://doi.org/10.17721/moca.2019.130-139 [23] Zolotov Yu., Varshal G., Ivanov V.: Analiticheskaya Khimiya Metallov Platinovoi Gruppy. Komkniga, Moskwa 2005.
[24] Ginzburg S., Shlenskaya N., Prokofieva I. et al.: Analiticheskaya Khimiya Platinovykh Metallov. Nauka, Moskva 1972.

[25] Levitskaya G., Timoshuk S., Gritsai V.: J. Anal. Chem., 2003, 58, 1065. https://doi.org/10.1023/A:1027385306485

[26] Bas B., Wegiel K., Jedlinska K.: Electrochim. Acta, 2015, 178, 665. https://doi.org/10.1016/j.electacta.2015.08.047

[27] Pérez-Ràfols C., Trechera P., Serrano N. et al.: Talanta, 2017,

167, 1. https://doi.org/10.1016/j.talanta.2017.01.084

[28] Ariño C., Serrano N., Díaz-Cruz J. et al:: Analyt. Chim. Acta,

2017, 990, 11. doi: 10.1016/j.aca.2017.07.069.

https://doi.org/10.1016/j.aca.2017.07.069

[29] Silwana B., Van der Horst C., Iwuoha E. et al.: Electrochim.

Acta, 2014, 128, 119. https://doi.org/10.1016/j.electacta.2013.11.045

[30] Locatelli C.: Electrochim. Acta, 2006, 52, 614.

https://doi.org/10.1016/j.electacta.2006.05.041

[31] Sladkov V., Prokhorova G., Ivanov V.: J. Anal. Chem., 2000, 55, 889. https://doi.org/10.1007/BF02757856

[32] Kolpakova N., Gorchakov E., Karachakov D.: J. Anal. Chem., 2009, 64, 44. https://doi.org/10.1134/S1061934809010092

[33] Patsay I., Rydchuk P., Tymoshuk O.: Visnyk Lviv Univ., 2017, 58, 219.

[34] Brauer G. (Ed.): Rukovodstvo po Neorganicheskomu Sintezu, v. 5. Mir, Moskva 1972.

[35] Rydchuk M.: PhD thesis, Ivan Franko National Univ., Lviv 2010.

[36] Rydchuk P., Tymoshuk O., Kharchuk R.: Pat. UA 101952, Publ.

Oct. 12, 2015.

[37] Rydchuk P., Tymoshuk O., Kharchuk R., Patsay I.: Pat. UA 126660, Publ. July 25, 2018.

[38] Vrublevska T., Rydchuk M., Bonishko O. et al.: Mater. Sci., 2010, 46, 108. https://doi.org/10.1007/s11003-010-9303-3

[39] Nazarenko V., Antonovich V., Nevskaya E. Gidroliz Ionov Metallov v Razbavlenykh Rastvorakh. Atomizdat, Moskva 1974. [40] Rakyts'ka T., Vasylechko V., Kiose T. et al.: Adsorp. Sci. Technol., 2017, 35, 482. https://doi.org/10.1177/0263617417697713 [41] Rakytskaya T., Vasylechko V., Kiose T. et al.: Chem. Met. Alloys, 2015, 8, 32. https://doi.org/10.30970/cma8.0301 [42] Rakytskaya T., Kiose T., Vasylechko V. et al::Chem. Met. Alloys, 2011, 4, 213. https://doi.org/10.30970/cma4.0186

[43] Oleksiv L.: PhD thesis, Ivan Franko National Univ., Lviv 2017.

Received: February 11, 2020 / Revised: March 10, 2020 / Accepted: July 01, 2020

\section{ВОЛЬТАМПЕРОМЕТРИЧНЕ ВИЗНАЧЕННЯ Рd(II) ПІСЛЯ ТЕРМІЧНОЇ АКТИВАЦЇ̈ ВЗАСМОДІї 3 5-ГІДРОКСИІМІНО-4- ІМІНО-1,3-ТІАЗОЛІДИН-2-ОНОМ}

\begin{abstract}
Анотація. Досліджено взаємодію Рd(II) $з$ 5-гідроксиіміно-4-іміно-1,3-тіазолідин-2-оном (ГІТО) в інтервалі рН 1,0-10,0. Встановлені оптимальні умови вольтамперометричного визначення Рd(II). Розроблено нову вольтамперометричну методику визначення Рd(II) за піком комплексу на фоні $\mathrm{NaCl}$ при рН 2,0 з межею визначення 2,0 $10^{-7} \mathrm{M}$. В роботі представлено дослідження селективності розробленої методики. Правильність методики підтверджено при аналізі модельних розчинів та реального об'єкта (резистора СП 5-35Б).
\end{abstract}

Ключові слова: паладій, вольтамперометричне визначення, азолідон, оксим, термічна активація. 